\title{
Iridovirus infections in farm-reared tropical ornamental fish
}

\author{
Ilan Paperna ${ }^{1, *}$, Margarita Vilenkin ${ }^{1}$, Antonio Pedro Alves de Matos ${ }^{2,3}$ \\ ${ }^{1}$ Department of Animal Sciences, Faculty of Agricultural, Food and Environmental Quality Sciences, \\ Hebrew University of Jerusalem, Rehovot 76100, Israel \\ ${ }^{2}$ Pathology Department, Curry Cabral Hospital, 1050 Lisbon, Portugal \\ ${ }^{3}$ Biomaterials Department, Dental Medical School, University of Lisbon, Portugal
}

\begin{abstract}
A systemic viral infection in both gourami Trichogaster spp. and swordtail Xiphophorus hellerii and an outbreak of lymphocystis in scalare Pterophyllum scalarae and gourami are reported to have occurred in fish reared in ornamental fish farms in Israel. The systemic infection developed in endothelial cells that became hypertrophic and their contents were modified. The presence of such cells in light-microscopically examined stained smears and sections provides an initial indication for this systemic viral infection. Infection in gourami caused hemorrhagic dropsy. Transmission electron microscopic (TEM) images of iridovirus-like particles recovered from gouramies showed them to be 138 to $201 \mathrm{~nm}$ from vertex to vertex (v-v); those from swordtails were 170 to $188 \mathrm{~nm} \mathrm{v}$-v. TEM images of lymphocystis virions from scalare were 312 to $342 \mathrm{~nm} \mathrm{v}-\mathrm{v}$ and from gourami 292 to $341 \mathrm{~nm} v$-v. Lymphocystis cells from the gourami were joined by a solid hyaline plate, which was lacking in the infection in scalare where the intercellular spaces between the lymphocystis cells consisted of loose connective tissue.
\end{abstract}

KEY WORDS: Trichogaster spp. Xiphophorus spp. Pterophyllum scalarae $\cdot$ Iridovirus-like particles · Systemic infection $\cdot$ Endothelium $\cdot$ Hypertrophy $\cdot$ Lymphocystis

Resale or republication not permitted without written consent of the publisher

\section{INTRODUCTION}

Systemic iridovirus-like infections have been reported from several exotic ornamental fish: in the cichlid Eutroplus maculatus imported from Singapore into Canada (Armstrong \& Ferguson 1989); in dwarf gourami Colisa lalia imported from south east Asia to Australia (Anderson et al. 1993); and in guppy Poecilia reticulata and doctor fish Labroides dimidatus in the USA, both South East Asian imports (Hedrick \& McDowell 1995). The first report on lymphocystis in freshwater ornamental fish was published in 1927, in an aquarium-held Macropodus sp. (Rasin 1927). Paperna et al. (1987) reported infection in a gourami Trichogaster pectoralis imported to Israel. In Israel, agreeable climatic conditions and export options en-

*E-mail: paperna@agri.huji.ac.il couraged the establishment of farms producing tropical ornamental fish. These farms have to rely on imported culture seed; however, such imports were shown to be potential vectors of infectious agents (Hedrick \& McDowell 1995).

Species of gourami Trichogaster spp., swordtail Xiphophorus hellerii, platy Xiphophorus maculatus and mollies Poecilia latipinna commercially reared in Israel suffered morbidity with conspicuous visceral pathology, while severe outbreaks of lymphocystis occurred in scalare Pterophyllus scalare and gourami Trichogaster leeri. To highlight the risks of introducing viral infection to the commercially farmed exotic tropical fish, we provide in the present communication an initial account of these viral infection outbreaks: light microscopic histocytopathological findings and demonstration by electron microscopy of the viral particles involved in these infections. Histopathological 
findings together with a demonstration of viral particles by electron microscopy prove to be useful in the differential diagnosis of causes of mortality in the farmed fish.

\section{MATERIALS AND METHODS}

Smears and touch preparations were air-dried, fixed with absolute methanol and stained with Giemsa (in pH 7.4 buffer, for $1 \mathrm{~h}$ ). For light microscopic histology, tissues were fixed in neutral-buffered formalin (exceptionally with aqueous Bouin's), and after dehydration in graded ethanols were embedded in glycol-methacrylate medium (Agar Scientific, Ltd, Stansted, UK). Sections, 2 to $3 \mu \mathrm{m}$, were cut with a glass knife on a Sorval JB4 microtome, and were stained with either Meyer's hemalum-eosin or, after a 20 min incubation in Bouin's solution and a water and $70 \%$ ethanol rinse, with $10 \%$ Giemsa in phosphate buffer, pH 7.4.

For transmission electron microscopy (TEM), fragments from tissue with conspicuous cytopathological changes were fixed in $2.5 \%$ glutaraldehyde in cacodylate buffer $(0.1 \mathrm{M}, \mathrm{pH} 7.4)$ for $24 \mathrm{~h}$ at $4^{\circ} \mathrm{C}$, rinsed repeatedly in the same buffer, post-fixed in $1.0 \%$ osmium tetroxide in the same buffer for $1 \mathrm{~h}$ and, after rinsing in the buffer, dehydrated in graded ethyl alcohols and embedded in Agar 100 medium (Agar Scientific, Ltd). Thin sections, cut on a Reichert Ultracut Microtome with a diamond knife, were stained on grid with uranyl acetate and lead citrate, and examined with a Jeol 100CX TEM. Semi-thin sections cut with a glass knife were stained with Toluidine blue.

\section{RESULTS}

\section{Viral hemorrhagic dropsy (VHD) in gourami}

Affected fish, observed on several occasions in stocks of farmed gourami of the species Trichogaster trichopterus (Fig. 1) and T. leeri, developed a dropsylike condition, with no other external clinical signs. On necropsy, abdominal cavities were found to be congested with hemorrhagic liquid. Many affected fish died. In one farm, the hemorrhagic dropsy in T. leeri coincided, in the same or different specimens, with heavy lymphocystis infections. In that farm, a systemic iridoviral infection also occurred in swordtails and apparently in other poecilids.

Histological sections showed numerous grossly hypertrophic cells, apparently endothelial, as they occurred in association with vascular elements. Cells had variably modified contents; their nucleus was often hypertrophic and vesiculated, and the nucleolus enlarged. In others the nuclei were fragmented or disaggregated into clumps of condensed chromatin (Fig. 2). The cytoplasm was either homogeneously fine granular, or had inclusions of either granular or dense hyalinized matter (Fig. 3).

When viewed by TEM, the hypertrophic cells were found to contain numerous virions, aggregated within an unbound inclusion of fibrogranular contents. The peripheral cytoplasm retained a network of endoplasmic reticulum and mitochondria (Figs 4 \& 5). Virions in all infected fish were of typical iridoviral structure, with icosahedral capsids containing an homogeneously electron-dense nucleoid. Some particles were deformed or incomplete. Virions recovered from Trichogaster trichopterus were $156 \pm 10 \mathrm{~nm}$ vertex to vertex $(v-v)$ and $130 \pm 8 \mathrm{~nm}$ from face to face (f-f), with a $81 \pm 10 \mathrm{~nm}$ nucleoid (Fig. 6). Those of T. leeri from 2 different farms were either $180 \pm 9 \mathrm{~nm} \mathrm{v}-\mathrm{v}$ and $150 \pm$ $8 \mathrm{~nm}$ f-f, with a $105 \pm 9 \mathrm{~nm}$ nucleoid (Fig. 7), or $174 \pm$ $7 \mathrm{v}-\mathrm{v}$ and $143 \pm 3 \mathrm{f}-\mathrm{f}$, with a $94 \pm 4$ nucleoid (Fig. 8, Table 1).

\section{Systemic infection in swordtail (SVIS)}

Infection was diagnosed in a farm where several varieties of swordtail Xiphophorus hellerii suffered persistent losses. None of the moribund fish developed hemorrhagic dropsy. Tissue touch and histological preparations from seemingly sick and moribund fish contained multitudes of grossly hypertrophic cells. Such cells occurred in most visceral tissues but were particularly common in the kidney (Figs 9 \& 10), the stomach submucosa and the intestine lamina propria. In the kidneys, the hypertrophic cells filled the glomeruli while being present in fewer numbers in the hematopoietic tissue (Fig. 9). The hypertrophic cells were similar in appearance to those observed in the infected gouramies with either an enlarged vesicu-

Figs 1 to 8. Viral hemorrhagic dropsy in gourami. Fig. 1. Trichogaster trichopterus with hemorrhagic viscera. Fig. 2. T. leeri liver with hypertrophic cells, with either enlarged or fragmented nuclei (arrows). Fig. 3. T. leeri hematopoietic kidney: enlarged view of hypertrophic cells, with either granular (arrow, bottom) or dense hyalinized cytoplasm (arrow, top). Fig. 4. Low magnification transmission electron microscopic (TEM) image of hypertrophic cell with an inclusion filled with iridovirus-like particles, T. leeri from farm C, kidney (e: endoplasmic reticulum; t: mitochondria). Fig. 5. Same type of image as in Fig. 4, from T. leeri from farm B. Arrows show limits of the infected cell. Fig. 6. Virions seen in T. trichopterus, from farm A. Fig. 7. Virions seen in T. leeri from farm B. Fig. 8. Virions seen in T. leeri from farm C. Scale bars: Figs 2, 3: $10 \mu \mathrm{m}_{i}$ Figs 4,5: $2 \mu \overline{\mathrm{m}}$; Fig. 6: $0.5 \mu \mathrm{m}_{i}$ Figs 7, 8: $0.25 \mu \mathrm{m}$ 


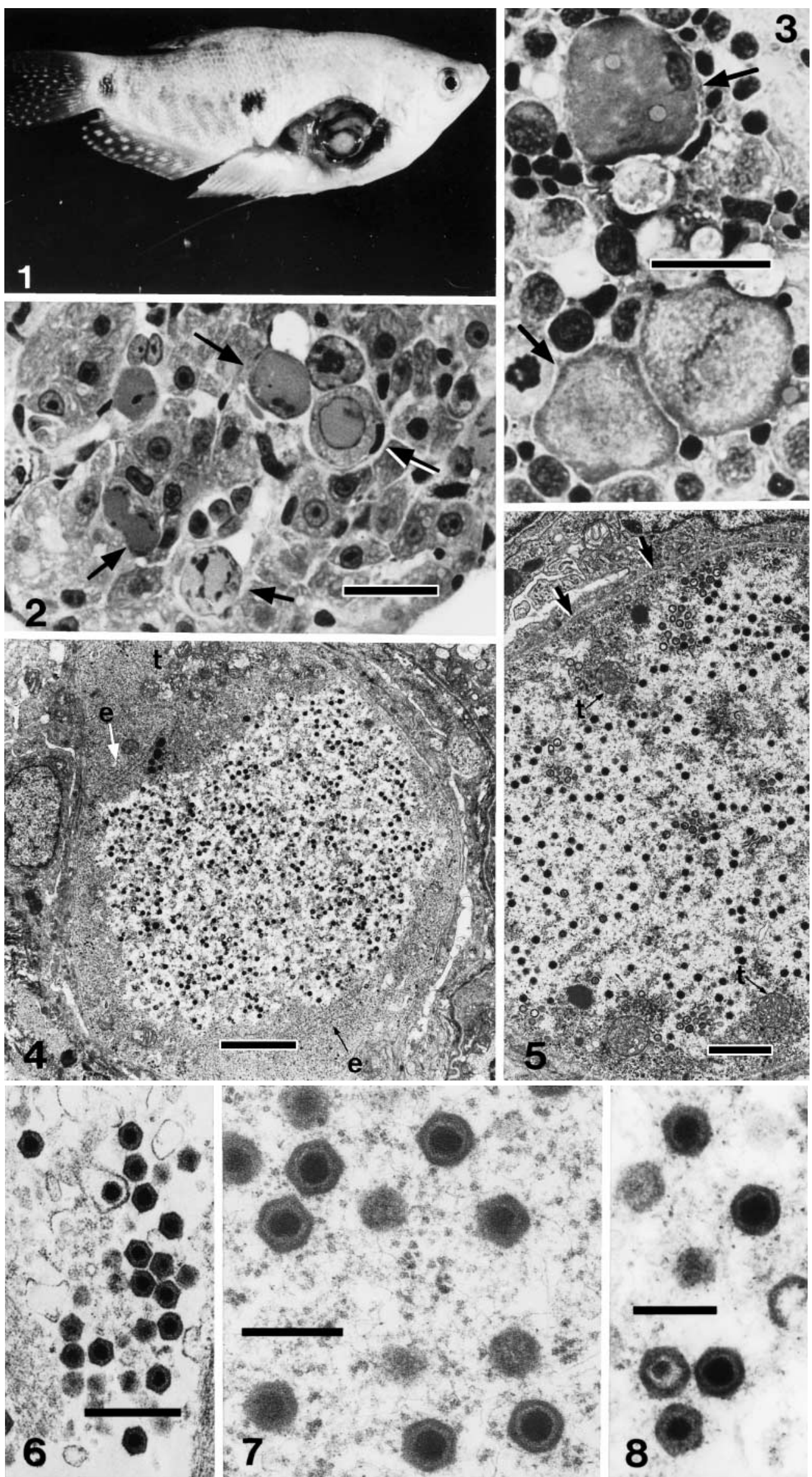




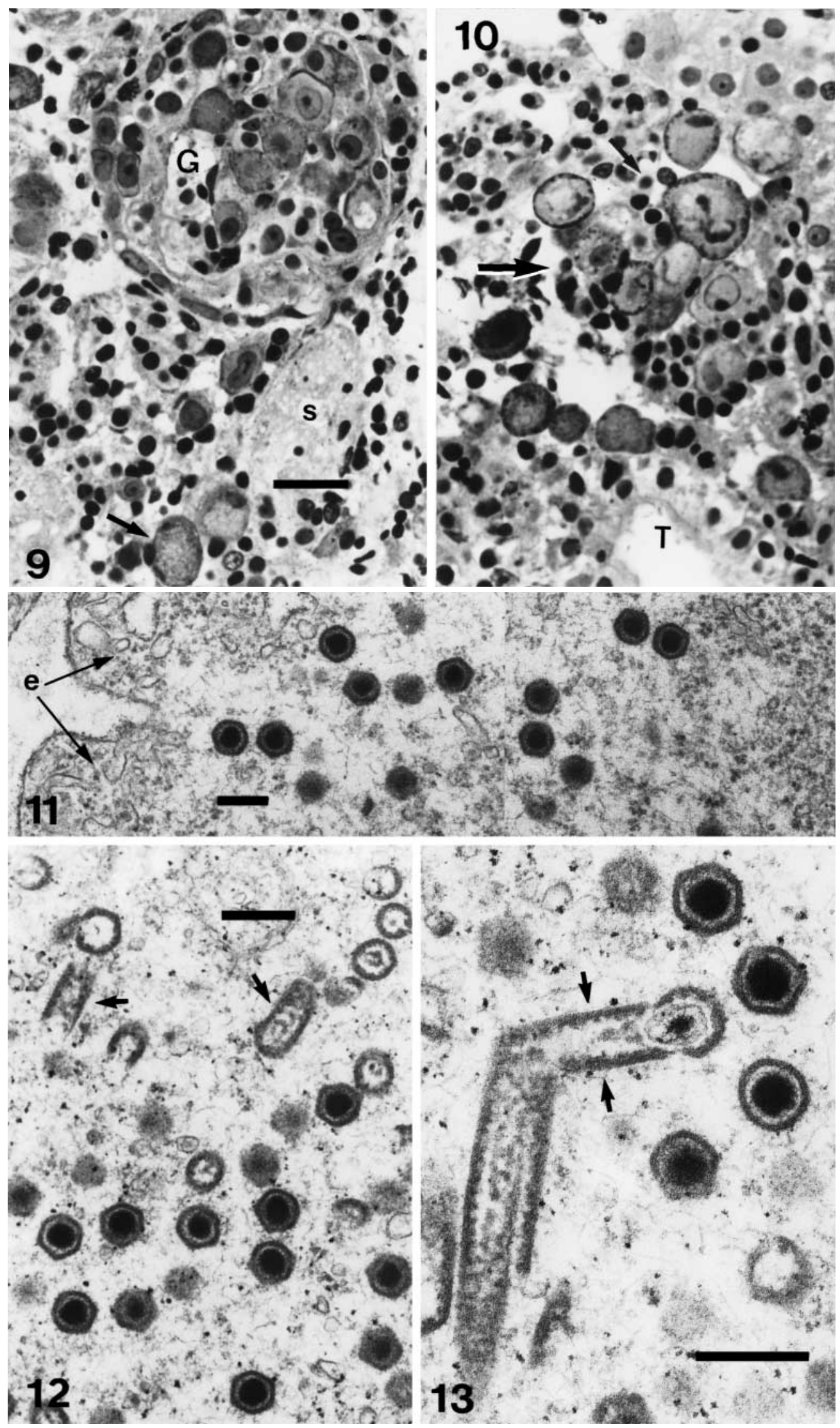


Figs 9 to 13. Iridovirus-like infection in swordtails Xiphophorus hellerii. Fig. 9. Hypertrophic cell either with enlarged nucleus and nucleolus or variably deformed in the glomerulus (G) and hematopoietic tissue (arrow) of a swordtail kidney (s: site of necrosis). Fig. 10. Aggregate of hypertrophic cells within the remains of a glomerulus in a swordtail kidney. T: renal tubule. Fig. 11. Virions within an inclusion in a hypertrophic cell (e: endoplasmic reticulum). Fig. 12. Virions and defunct particles: capsid and cylinder-like structures (arrows). Fig. 13. Virions and long cylinder-like structure (arrows) emerging from an apparently deformed particle. Scale bars: Figs 9,10: $10 \mu m_{i}$ Figs 11,12,13: $0.25 \mu \mathrm{m}$
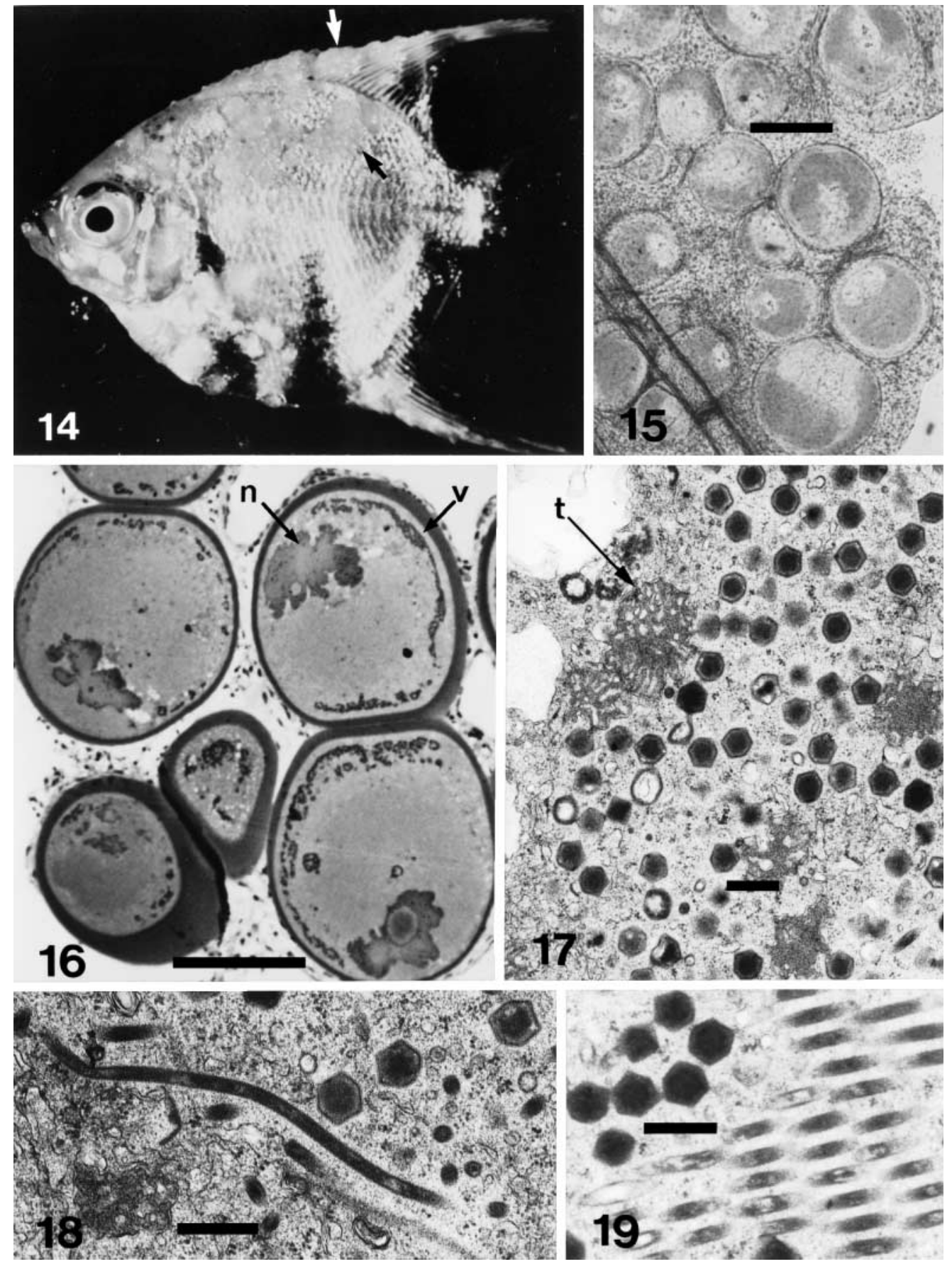

Figs 14 to 19. Lymphocystis in Pterophyllum scalarae. Fig. 14. Infected fish; nodules of lymphocystis cells are marked with arrows. Fig. 15. Light microsopy view of fresh lymphocystis nodule. Fig. 16. Histological view of lymphocystis cells stained with Bouin's Giemsa. Fig. 17. TEM image of virions in the cytoplasm of lymphocystis cell (t: mitochondria). Fig 18. Elongate tubular structures and virions. Fig. 19. Tubular structures aligned into an irregularly spaced formation among arrays of virions. Scale bars: Figs 15,16: $100 \mu \mathrm{m}$; Figs 17,18,19: $0.5 \mu \mathrm{m}$ 
Table 1. Dimensions of reported iridoviruses (mean \pm SD and size range). *From Paperna et al. (1987); \#early- and \#\#late-stage infections. SVIS: systemic infection in swordtail; VHD: viral hemorrhagic dropsy

\begin{tabular}{|c|c|c|c|c|c|c|}
\hline $\begin{array}{l}\text { Type of } \\
\text { infection }\end{array}$ & Host & $\begin{array}{l}\text { Locality } \\
\text { and date }\end{array}$ & $\mathrm{n}$ & $\begin{array}{l}\text { Vertex to } \\
\text { vertex }(\mathrm{nm})\end{array}$ & $\begin{array}{c}\text { Face to } \\
\text { face }(\mathrm{nm})\end{array}$ & Nucleotide \\
\hline VHD & Trichogaster trichopterus & Farm A 1992 & 17 & $\begin{array}{c}156 \pm 10 \\
(138-176)\end{array}$ & $\begin{array}{l}130 \pm 8 \\
(120-148)\end{array}$ & $\begin{array}{c}81 \pm 10 \\
(65-102)\end{array}$ \\
\hline VHD & T. leeri & Farm B 1995 & 14 & $\begin{array}{l}180 \pm 9 \\
(165-201)\end{array}$ & $\begin{array}{l}150 \pm 8 \\
(142-165)\end{array}$ & $\begin{array}{l}105 \pm 9 \\
(94-130)\end{array}$ \\
\hline VHD & T. leeri & Farm C 1998 & 14 & $\begin{array}{c}174 \pm 7 \\
(164-186)\end{array}$ & $\begin{array}{l}143 \pm 3 \\
(137-143)\end{array}$ & $\begin{array}{c}94 \pm 4 \\
(88-102)\end{array}$ \\
\hline SVIS & $\begin{array}{l}\text { Xiphophorus hellerii } \\
\text { subspp. }\end{array}$ & Farm C 1998 & 20 & $\begin{array}{l}181 \pm 5 \\
(170-188)\end{array}$ & $\begin{array}{l}156 \pm 8 \\
(141-160)\end{array}$ & $\begin{array}{l}102 \pm 9 \\
(84-123)\end{array}$ \\
\hline Lymphocystis & Pterophyllus scalarae & Farm D 1998 & 21 & $\begin{array}{c}331 \pm 10 \\
(312-342)\end{array}$ & $\begin{array}{l}281 \pm 17 \\
(267-312)\end{array}$ & $\begin{array}{c}215 \pm 14 \\
(193-238)\end{array}$ \\
\hline Lymphocystis & T. trichopterus & Pet shop $1986^{*}$ & $\left({ }^{*}\right)$ & $\begin{array}{l}190-243 \# \\
216-264 \# \#\end{array}$ & $\begin{array}{l}138-160 \# \\
166-216 \# \#\end{array}$ & \\
\hline Lymphocystis & T. leeri & $\begin{array}{l}\text { Farm C } \\
1998\end{array}$ & 19 & $\begin{array}{l}320 \pm 17 \\
(292-341)\end{array}$ & $\begin{array}{l}261 \pm 16 \\
(243-292)\end{array}$ & $\begin{array}{c}205 \pm 12 \\
(195-219)\end{array}$ \\
\hline \multicolumn{3}{|c|}{$T$-tests between measured dimensions of the following viruses: } & \multicolumn{4}{|c|}{$\begin{array}{l}\text { T. trichopterus VHD versus T. leeri VHD }(\mathrm{v}-\mathrm{v}): 7.09 ; \mathrm{p}<0.01 \\
\text { T. leeri VHD versus } X \text {. hellerii SVIS }(\mathrm{v}-\mathrm{v}): 0.47 ; \mathrm{p}>0.05 \\
\text { T. leeri VHD versus } X \text {. hellerii SVIS (f-f): } 1.8 ; \mathrm{p}>0.05 \\
\text { T. leeri versus } P \text {. scalarae lymphocystis (v-v): } 2.42 ; \mathrm{p}=0.01\end{array}$} \\
\hline
\end{tabular}

lated nucleus and large nucleolus, or a deformed, residual or fragmented nucleus. Their cytoplasm either contained variably sized and shaped inclusions of faint eosinophilic matrix or was almost entirely filled with fine granular substance (Fig. 10). TEM images from the hypertrophic cells revealed expanded inclusions of fibrogranular cytoplasm filled with iridovirus-like particles, of $181 \pm 5 \mathrm{~nm} \mathrm{v}-\mathrm{v}, 156 \pm 8 \mathrm{~nm} \mathrm{f}-\mathrm{f}$ and $102 \pm 9 \mathrm{~nm}$ electron-dense nucleoid (Figs 11, 12 \& 13). Among the aggregating viruses, there occurred empty and deformed capsid-like structures (Fig. 12) together with elongate tubular or cylinder-like structures, $132 \mathrm{~nm}$ in diameter (Fig. 13); these may be abnormally assembled viral proteins.

In the same farm, hypertrophic cells were found in examined platies Xiphophorus maculatus and mollies Poecilia latipinna. The repeatedly histologically and cytologically examined guppies Poecilia reticulata reared on the same farm were never found to have the hypertrophic cells characteristic of iridoviral infection. Such cells were also absent in reared dwarf gourami Colisa lalia.

\section{Lymphocystis infection of scalare}

This infection has so far been found to affect scalare Pterophyllus scalarae from only 1 farm. Fish were heavily infected (Fig. 14) and many died. Ultimately the entire stock was destroyed. The heaviest concen- tration of hypertrophic cells was on the dorsal half of the fish and on fins; the overload of hypertrophic cells, in some fish, led to skin abrasions (Fig. 15). Hypertrophic cells varied in size, which could suggest an active infection, and were all enclosed in a thick hyaline capsule, intensely stained with basophilic dyes. The matrix surrounding the lymphocystis cells consisted of loose connective tissue. The fairly homogeneously granular cytoplasm contained basophilic winding inclusions extending along the cell periphery and large lobular nucleus, and the nucleolus either was retained or had disintegrated (Fig. 16). Virions in TEM-examined cells were $331 \pm 10 \mathrm{~nm} \mathrm{v}$-v and $281 \pm$ $17 \mathrm{~nm}$ f-f, and had a usually homogeneously electrondense nucleoid, $215 \pm 14 \mathrm{~nm}$ (Fig. 17). Alongside were also incomplete virions and empty capsids. Virions were accompanied by numerous tubular, cylindrical structures, $89 \mathrm{~nm}$ in diameter, some very long (Fig. 18). These appeared to be the same abnormally assembled viral structures seen in the swordtail viral infection. Some cylinders formed groups of aligned structures separated by very regular spaces (Fig. 19). The cytoplasm contained a fair number of seemingly distorted mitochondria (Fig. 17).

\section{Lymphocystis in gouramies}

The same stock of Trichogaster leeri found affected by the systemic iridovirus-like infection was also in- 


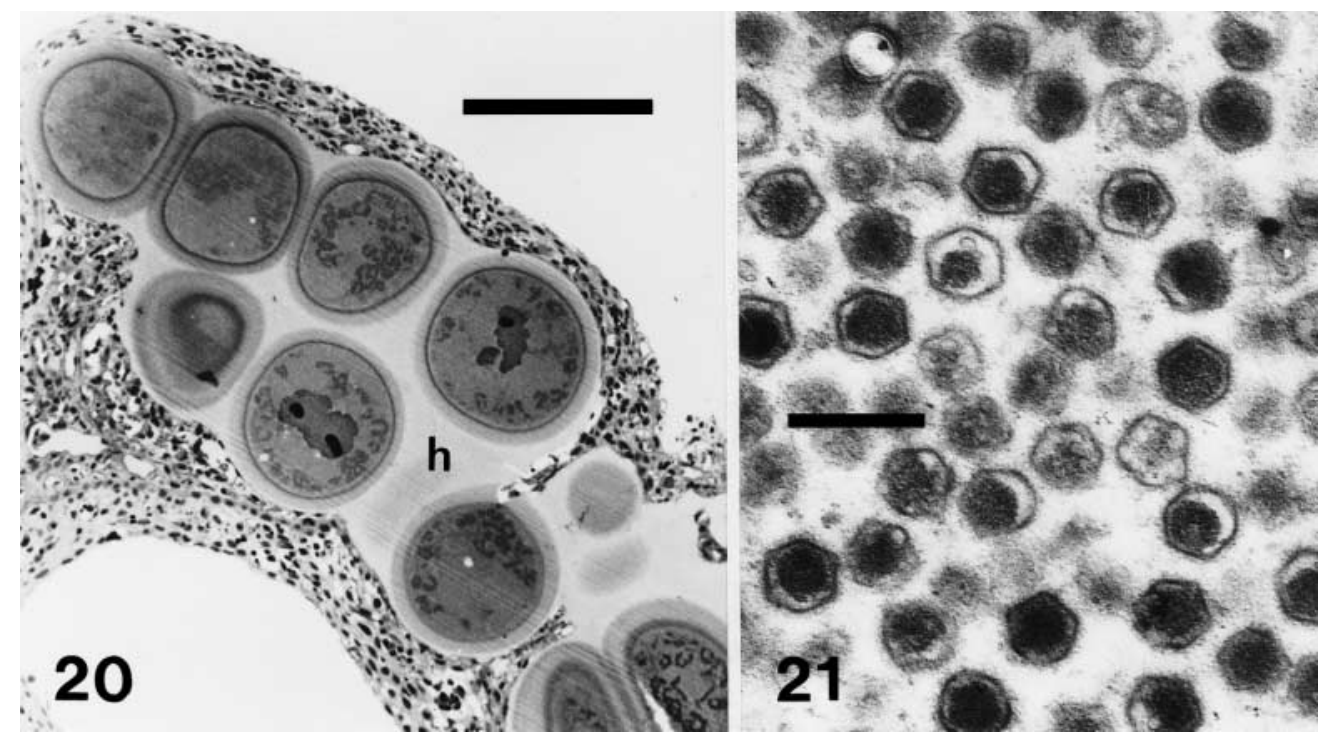

Figs 20 \& 21. Lymphocystis from Trichopterus leeri. Fig. 20. Lymphocystis cells embedded into a hyalin matrix (h). Fig. 21. TEM image of virions in a lymphocystis cell. Scale bars: Fig. 20: $100 \mu \mathrm{m}$; Fig. 21: $0.25 \mu \mathrm{m}$

fected with lymphocystis; in some fish both viral infections co-existed. Infection in some dying fish was extreme; fish, however, could succumb to either or both systemic viral and lymphocystis dermal infections; such fish had dropsy as well as dermal lesions. Aggregates of hypertrophic cells were scattered all over the skin; upon histological examination the deeply basophilic hyalinized wall was embedded in hyaline, moderately basophilic, expanded plate (Fig. 20). The homogeneously granular cytoplasm contained a dense network of basophilic inclusions and an enlarged invaginated nucleus, sometimes retaining 1 or more nucleoli. Virions in TEM images of lymphocystis cells were $320 \pm 17 \mathrm{~nm} \mathrm{v}$-v and $261 \pm 16 \mathrm{~nm} \mathrm{f-f}$, with a $205 \pm$ $12 \mathrm{~nm}$ nucleoid. The capsid wall was thinner (and sometimes distorted) than in all of the above descibed virions (Fig. 21).

\section{DISCUSSION}

The purpose of this communication is to present a first report on the presence of viral infections in commercially farmed exotic tropical fish in Israel. Among VHD-infected gouramies, 3 significant particle-size groups were detected, which, moreover, in all instances, were larger (>170 nm) than the iridovirus-like particles reported from dwarf gouramies Colisa lalia in Australia (117 to $137 \mathrm{~nm}$, mean: $125 \pm 1 \mathrm{~nm}$; Anderson et al. 1993). At the same time, size differences between viral particles from gourami and swordtail fish were not significant, which might imply that gouramies and swordtails that cohabited the same farm were cross- infected. Hyatt et al. (2000) suggested that differences in particle sizes reflect subdivision within Ranavirus and among iridoviruses. Particle mean v-v from systemic infections observed in our study ranged from 156 to $181 \mathrm{~nm}$, covering nearly the entire range of particle sizes listed by Hyatt et al. (2000). The mean particle size of the iridoviruses from guppies (GV6) and doctor fish (DFV) imported from South East Asia studied in the USA were 162 and $163 \mathrm{~nm}$, respectively (Hedrick \& McDowell 1995, Hyatt et al. 2000). A similarly wide variability in particle size was found among viral infections infecting South East Asian marine fish (Chua et al. 1994, Miyata et al. 1997). Our data also confirm previously reported findings showing a clear division in size between the iridovirus-like particles present in systemic infections and those in lymphocystis. The capsid of lymphocystis viruses, particularly from gourami, appears to be thinner (and seemingly more fragile) than the iridovirus-like virions of systemic infections. Fragility of lymphocystis capsids was detected in comparison with frog virus 3 (FV3) and chilo iridescent virus (CIV) by Heppell \& Berthiaume (1992). Thin capsids are also evident in images of previously reported lymphocystis virions from gourami (Paperna et al. 1987) and other fish (Howse \& Christmas 1971, Howse 1972, Lawler et al. 1974); they are less evident in lymphocystis infecting Sparus aurata (Paperna et al. 1982). Aubertin (1991) proposed placing visceral iridoviruses and lymphocystis in separate genera within the family Iridoviridae.

Confirmation of the relationship or divergence among systemic as well as between lymphocystis-inducing iridoviruses, in addition to visual evidences, e.g., dif- 
ferences in size and configuration, requires characterizing purified viral material by a variety of molecular approaches (Hedrick \& McDowell 1995, Mao et al. 1997). The iridovirus-like causative agents of systemic infections of fish, related by their properties with epizootic hematopoietic necrosis virus (EHNV) originally isolated from Perca fluviatilis in Australia (Langdon 1989), have been shown to have strong affinity with systemic amphibian viruses grouped into the genus Ranavirus (Hyatt et al. 2000). The 7th report of the International Committee on Taxonomy of Viruses confirms the classification of the piscine hematopoietic necrosis viruses as Ranavirus (Williams et al. 2000).

Data from Hyatt et al. (2000) generated from a range of molecular techniques indicate that GV6 and DFV, both imported from South East Asia, are not members of the genus Ranavirus. Hyatt et al. (2000) regarded of uncertain taxonomic position the iridovirus-like particles recovered from South East Asian freshwater and marine fish that produce hypertrophic cells in the lamina propria and epidermis, and within organs such as kidney and spleen (Armstrong \& Ferguson 1989, Jung et al. 1997, Miyata et al. 1997, He et al. 2000, Jung \& Oh 2000). The systemic iridoviral infection reported in our study found in fish, originally imported from South East Asia, similarly induces hypertrophy of the infected host cells. The 'large amoeba-like' organisms in the submucosal tissue described by Anderson et al. (1993) from the dwarf gourami intestine also seem likely to be hypertrophic virus-infected cells.

Infection in both gouramis and swordtails developed in endothelial cells and induced the same cytopathological changes: hypertrophy and vesiculation. Hemorrhagic dropsy was noted, but only in gouramies. In swordtails, the entire glomerulus was invaded by hypertrophic cells; in gourami only a few hypertrophic cells occurred in the glomeruli. These differences result from variation in infection severity among different stocks of fish, from interspecific variation in susceptibility to the same virus or from evidence for infection by different viruses. Evidence of such cells by histopathology was found to be useful in a preliminary detection of the infection. In EHNV infection, on the other hand, the cytopathic changes observed did not involve cell hypertrophy. Infected fish displayed necrosis of the hematopoietic renal tissue with variable involvement of the pancreas and spleen (Langdon 1989).

The earlier case of lymphocystis in gourami was from a few fish from a pet shop, with no evident clinical consequences. Lymphocystis has developed into a massive outbreak in commercially reared fish of a different gourami species and resulted in mortalities. Lymphocystis in these fish, however, coincided with viral systemic infection and complicated the etiological circumstances.
Lymphocystis cells from different fish diverge distinctly in their histological character. This strongly suggests that lymphocystis infections are highly host specific. The observed structural variation in lymphocystis involves not only their cell wall and the cytoplasmic configuration but also the nature of the intercellular matrix that binds the mass (tumor) of the lymphocystis cells (Howse \& Christmas 1970). The hyaline substance of the cell boundary (which contains acid mucosubstances) may extend to form an intercellular matrix, ranging in consistency from very thin strands to a broad hyaline plate. Lymphocystis cells from the gourami are joined by a solid hyaline plate, lacking altogether in the lymphocystis from scalare, where the intercellular spaces consist of loose connective tissue. Although the matrix is histochemically similar to the hyaline cell wall, it is less intensely stained, due to either differences in thickness or lower density of mucopolysaccharide polymers; chemical differences, however, cannot be entirely excluded (Howse \& Christmas 1970).

The cylinders formed in images of both virusinfected endothelial cells of the gourami Trichogaster leeri and lymphocystis from scalare appear to be a common phenomenon in iridoviridal replication. Cylinders can be made of capsid proteins as are the cylinders seen in African swine fever (Els \& Pini 1977) and in frog virus 3 (Tripier-Darcy et al. 1984), which are often seen to be continuous with polyhedral capsids (Els \& Pini 1977). The regular spacing of the cylinders suggests that they are separated by an outer, low-density layer of fibers, which can sometimes be seen at the virion surface.

\section{LITERATURE CITED}

Anderson IG, Prior HC, Rodwell BJ, Harris GO (1993) Iridovirus-like virions in imported dwarf gourami (Colisa lalia) with systemic amoebiasis. Aust Vet J 70:66-67

Armstrong RD, Ferguson HW (1989) A systemic viral disease of chromide cichlids, Eutroplus maculatus Bloch. Dis Aquat Org 7:155-157

Aubertin AM (1991) Family iridoviridae. In: Francki RIB, Fauquet CM, Knudson DL, Brown F (eds) Classification and nomenclature of viruses. Fifth report of the International Committee on Taxonomy of Viruses. Arch Virol Suppl 2:132-136

Chua IHC, Ng ML, Ng KL, Loo JJ, Wee JY (1994) Investigation of outbreaks of a novel disease, 'sleepy grouper disease' affecting the brown spotted grouper Epinephelus tauvina Forskal. J Fish Dis 17:417-427

Els HJ, Pini A (1977) Negative staining of a non-hemadsorbing stain of African swine fever virus. Onderstepoort J Vet Res 44:39-46

He JG, Wang SP, Zeng K, Huang ZJ, Chan SM (2000) Systemic disease caused by a iridovirus-like agent in cultured mandarinfish, Siniperca chuatsi (Basilewski), in China. J Fish Dis 23:219-222 
Hedrick RP, McDowell TS (1995) Properties of iridoviruses from ornamental fish. Vet Res 26:423-427

Heppell J, Berthiaume L (1992) Ultrastructure of lymphocystis disease virus (LDV) as compared to frog virus 3 (FV3) and and chilo iridescent virus (CIV): effect of enzymatic digestions and detergent degradations. Arch Virol 125:215-226

Howse HD (1972) Snook (Centropomus: Centropomidae): new host for lymphocystis, including observation on the ultrastructure of the virus. Am Midl Nat 88:476-479

Howse HD, Christmas JY (1970) Lymphocystis tumors: histochemical identification of hyaline substance. Trans Am Microsc Soc 89:276-282

Howse HD, Christmas JY (1971) Observation on the ultrastructure of lymphocystis virus in the Atlantis Croaker, Micropogodon undulatus (Linneaus). Virology 44:211-214

Hyatt AD, Gould AR, Zupanovic Z, Cunningham AA, Hengstberger S, Whittington RJ, Kattenbelt J, Coupar BEH (2000) Comparative studies of piscine and amphibian iridoviruses. Arch Virol 145:301-331

Jung SJ, Oh MJ (2000) Iridovirus-like infection associated with high mortalities of striped beakperch, Oplegnathus fasciatus (Temminck et Schlegel), in southern coastal areas of the Korean peninsula. J Fish Dis 23:223-226

Jung S, Miyazaki T, Miyata M, Danayadol Y, Tanaka S (1997) Pathogenicity of iridovirus from Japan and Thailand for the red sea bream Parus major in Japan, and histopathology of experimentally infected fish. Fish Sci 63:735-740

Langdon JS (1989) Experimental transmission and pathogenicity of epizootic haematopoietic necrosis virus (EHNV) in

Editorial responsibility: Jo-Ann Leong,

Corvallis, Oregon, USA redfin perch, Perca fluviatilis L., and 11 other teleosts. J Fish Dis 12:295-310

Lawler AR, Howse HD, Cook DW (1974) Silver perch Bairdiella chrysura: new host for lymphocystis. Copeia 1974: 266-269

Mao J, Hedrick RP, Chinchar VG (1997) Molecular characterization, sequence analysis, and taxonomic position of newly isolated fish iridoviruses. Virology 229:212-220

Miyata M, Matsuno K, Jung SJ, Danayadol Y, Miyazaki T (1997) Genetic similarity of iridoviruses from Japan and Thailand. J Fish Dis 20:127-134

Paperna I, Sabnai I, Colorni A (1982) An outbreak of lymphocystis in Sparus aurata L. in the Gulf of Aqaba, Red Sea. J Fish Dis 5:433-437

Paperna I, Ventura TM, de Matos AP (1987) Lymphocystis infection in snakeskin gourami, Trichogaster pectoralis (Regan), (Anabantidae). J Fish Dis 10:11-19

Rasin K (1927) Prispevek k pathogenesi Lymphocystis johstonei Woodcock. 1. [Data on the pathogenesis of L. johnstoni]. Biol Spisy Vysoke Zverolek Brno 6:11-38 (in Czech)

Tripier-Darcy F, Nermut MV, Braunwald J, Williams LD (1984) The organization of FV3 as revealed by freezeetching. Virology 138:287-299

Williams T, Chinchar D, Darai G, Hyatt A, Kalmakoff J, Seligy V (2000) Iridoviridae. In: Van Regenmortel MHV, Fauquet CM, Bishop DHL, Carstens EB and 6 others (eds) Virus taxonomy. Seventh Report of the International Committee on the Taxonomy of Viruses. Academic Press, New York, p 167-182

Submitted: February 23, 2001; Accepted: July 26, 2001 Proofs received from author(s): December 10, 2001 